\title{
Career opportunities of Honor Graduates and Student Leaders: The case of STO Domingo District
}

\author{
Rouselle U. Rara ${ }^{1}$, Sally V. Mateo ${ }^{2}$, Gener S. Subia ${ }^{3}$ \\ ${ }^{1}$ Teacher III, Baloc Elementary School, Doctor of Education Student, Wesleyan University Philippines \\ ${ }^{2,3}$ Graduate School, Faculty, Wesleyan University, Philippines
}

Received: 06 Nov 2020; Received in revised form: 05 Dec 2020; Accepted: 09 Dec 2020; Available online: 15 Dec 2020

(C)2020 The Author(s). Published by Infogain Publication. This is an open access article under the CC BY license

(https://creativecommons.org/licenses/by/4.0/).

\begin{abstract}
This tracer study was conducted in Sto. Domingo District, Schools Division of Nueva Ecijato determine the career opportunities of 117 elementary student leaders and honor graduates from 1989 to 1993. Using the questionnaire designed by Hirschi, et.al. (2018), the data revealed that the majority of the respondents were female,40 years old, married, and were bachelors' degree holders. Most of them were permanent in their work with a salary range of P46,000 and above. Their field of work was in education and have experienced at least 1 promotion for the last 5 years.The respondents claimed that their co-workers envisioned them as experts and possess profound knowledge in their occupation. Further, their current job fully challenged them and helped increase their skills. Additionally, the respondents have a clear understanding of what they want to achieve in their career and certain that their work-related abilities and knowledge are up-to-date. Also, the educational attainment and type of work of respondents were highly correlated with their career opportunities. The findings of this research have significant reverberations for the career-guidance program of the Department of Education.
\end{abstract}

Keywords - Career opportunities, honor graduates, student leaders, tracer study, work-related abilities.

\section{INTRODUCTION}

For the past 200 years, many countries have questioned the value of early childhood education and what role this early education plays in subsequent academic achievement and socialization in the primary grades. The classroom social environment plays avital part in the growth of school-age children. Student experiences within the classroom helps develop their behavioral, social, and academic skills. The quality of interactions that students have with their teachers predicts later success. Steinmayr et. Al (2014) stated that Early Childhood achievements include attaining the highest rank/grade and being a student leader. Furthermore, engaging students in early experiences in leadership creates the foundation for future leadership development which may lead to career success (Murphy \& Johnson, 2011).
Astin (1999) predicted that participation in honors programs can have a positive impact on both the educational and career aspirations of students and may help encourage students who are contemplating to continue their education beyond undergraduate to obtain a master's or doctoral degree. Participation in honors programming can also help students with advanced skills or talents in multiple areas (i.e., multipotentiality) narrow their options to focus on educational and career paths and opportunities that best fit their skills and their interests (Robinson, Shore, \& Enersen, 2007) in order to succeed.

As stated by Shahibudin (2015), "Generally, research on career success benefits individuals and organizations". "At the individual level, career success refers to the acquisition of materialistic advancement, power, and satisfaction (Judge, 
et.al.,1995)". "Thus, knowledge of career success helps individuals develop appropriate strategies for career development (Aryee, et.al., 1994)" while "at the organizational level, knowledge of the relationship between individual difference and career success helps human resource managers design effective career systems (Judge, et.al.,1995)".

Moreover, Ishak (2015) stated that "career success can be subdivided into two different components in terms of external or extrinsic components. For example, the external component consists of an employee's salary level, total compensation, salary progression, the number of promotions, and the internal or intrinsic components (the employee's job, career, and life satisfaction levels). They have agreed that, in order to investigate career success, both dimensions of career success (extrinsic/intrinsic or objective/subjective) should be studied together".

These lead the researchers to ask the following questions as what are the possible career opportunities of education achievers? More importantly, what does scholastic achievement have to do with career opportunities? And lastly, is there a relationship between educational achievement and career opportunities? Thus, this study was crafted. It aimed to trace the education achievement of elementary achievers ofSto. Domingo, Nueva Ecija until they became professionals and assess their present career opportunities.

\section{METHODOLOGY}

This study utilized the quantitative approach of research using descriptive as its design. The researcher adopted the questionnaire used by Hirschi, A. et. Al (2018) in their study entitled "Assessing Key Predictors of Career Success: Development and Validation of the Career Resources Questionnaire". The respondents of the study were 117 Valedictorians, Salutatorians, Honorable Mentions, and Student Leaders of elementary graduates from 1989-1993 in the Department of Education, Sto. Domingo District,
Schools Division of Nueva Ecija. Data gathered were analyzed using frequency, percentage, ranking, weighted mean, Spearman's rho, and Pearson's r.

\section{RESULTS AND DISCUSSION}

\section{Profile of the Respondents}

A great percentage of the respondents was 40 years old. More than $70 \%$ were females and $78.6 \%$ were married. It can be noted that more than $50 \%$ were Bachelor's degree holders and most of them were teachers. The data revealed that $62.4 \%$ of the respondents were permanent in their workwith a monthly salary range from 46,000 and above and had one promotion for the last 5 years.

\section{Education Achievement of the Respondents}

Table 1 shows the Education Achievements of the respondents which include Elementary Level Achievement, Secondary Level Achievement, and Tertiary Level Achievement.It can be seen that there was 29.06 percent of the respondents graduated from elementary as valedictorians. 17.09 percent of the respondents graduated from elementary as student leaders.It can be noted that 34.19 percent of the respondents graduated as Honorable mention, 33.33 percent of the respondents graduated with no awards and 5.13 percent of the respondent graduated as salutatorian. Interestingly, only 13 who were valedictorians in the elementary level maintained their position at the secondary level. The data revealed that there was 60.68 percent of the respondents finished the tertiary level with no academic achievements. Three (3) or 2.56 percent of the graduated as Magna Cum Laude; 13.68 percent of the respondents were Dean's Listers; 8.55 percent of the respondent were Cum laude and 14,53 of the respondents were student leaders. The education achievements of the respondents during elementary were as valedictorian, salutatorian, with honors, and as student leaders. Most of the respondents graduated from secondary level with honorable mention but graduated their tertiary level with no academic achievement. 
Table 1. Education Achievement of the Respondents

\begin{tabular}{ccc} 
Elementary Level Achievement & Frequency & percentage \\
\hline Valedictorian & 34 & 29.06 \\
Salutatorian & 31 & 26.5 \\
Honorable Mention & 32 & 27.35 \\
Student Leader & 20 & 17.09 \\
High School Achievement & Frequency & percentage \\
\hline Valedictorian & 13 & 11.11 \\
Salutatorian & 6 & 5.13 \\
Honorable Mention & 40 & 34.19 \\
Student Leader & 19 & 16.24 \\
None & 39 & 33.33 \\
Tertiary Level Achievement & Frequency & Percentage \\
\hline Magna Cum Laude & 3 & 2.56 \\
Cum Laude & 10 & 8.55 \\
Dean's Lister & 16 & 13.68 \\
Student Leader & 17 & 14.53 \\
None & 71 & 60.68
\end{tabular}

\section{Career Opportunities}

The key areas of Career Opportunities consist of Human Capital Resources, Environmental Resources, Motivational Resources, and Career Management Behaviors.

\subsection{Human Capital Resources of the Respondents}

The data revealed that from among the responses, item number 2 "I possess profound knowledge in my occupation" obtained the highest weighted mean of 3.32 described as "Completely True". On the other hand, item number 5, "I have a good overview of employment trends in the labor market" had the lowest weighted mean of 2.85 and described as "Mostly True". It can be implied that since the majority of the respondents have profound knowledge of their occupation, they possess skills, ability, and competence in their work to be able to perform their tasks effectively. In support of the study, Nassazi (2013) stated that "human resources are the intellectual property of the firm and employees prove to be a good source of gaining competitive advantage, thus, training is the only way of developing organizational intellectual property through building employees' competencies in order to succeed. Organizations have to obtain and utilize human resources effectively.
Organizations, therefore, need to design their human resource management in ways that fit into the organization's structure as this will make the organizations achieve their goals and objectives". Moreover, it is also important for organizations to assist their workforce in obtaining the necessary skills needed to increase commitment.

\subsection{Environmental Resources of Respondents}

In this career opportunity, the overall verbal description shows that it is "mostly true" revealing an overall weighted mean of 3.19.It also showed that among the responses, item number 9 "My work helps me to increase my skills" obtained the highest weighted mean of 3.45 verbally described as "Completely True". On the other hand, item number 2 "My organization holds many interesting positions for my future career" had the lowest weighted mean of 3.03 and described as "Mostly True". The study of Boles et al. (2004) indicated that "when employees are physically and emotionally fit they will have the desire to work and their performance outcomes will likewise increase. Moreover, a proper workplace environment helps in reducing the number of absenteeism and thus can increase the employees' performance which leads to increased productivity at the workplace". 


\subsection{Motivational Resources of Respondents}

The overall verbal description shows that it is "Completely True" revealing a weighted mean of 3.29. Among the responses, item number 8 "I have a clear understanding of what I want to achieve in my career." obtained the highest weighted mean of 3.40 described as "Completely True". On the other hand item number 1 "My work is a central part of my identity" had the lowest weighted mean of 3.18 and described as "Mostly True".Based on the results of the study, the respondents have strong motivational resources. It is widely recognized in human resource literature that the motivation of workers in both private and public organizations leads to a higher quality of human resources and optimum performance. According to Story et al. (2009), "individuals who are high in intrinsic motivation seem to prefer challenging cognitive tasks and can self-regulate their behaviors, so offering rewards, setting external goals, or deadlines will do little for them unless they are also high in extrinsic motivation. For employees high in intrinsic motivation, emphasis could be placed on the engaging nature of the task and encouragement of self-set goals and deadlines (Story et al., 2009)".

\subsection{Career Management Behavior of Respondents}

The overall verbal description shows that it is "Mostly True" revealing an overall weighted mean of 3.11. Item number 9 "I make sure that my work-related abilities and knowledge are up-to-date." obtained the highest weighted mean of 3.36 described as "Completely True". On the other hand item number 3 "I frequently utilize contacts with other people to advance in my career" and item number 5 "I constantly stay up-to-date about employment opportunities in the labor market." had the lowest weighted mean of 2.91 and described as "Mostly True". Employees' favorable attitude toward their job motivates them to work harder, and be involved, or engaged in their job. Motivated employees are likely to perform better in the organization with enhanced and effective productivity. The result is supported by the findings of Bakker \& Leiter (2010) as they mentioned that employees who are more engaged in their jobs have a lot of energy and can focus on their job effectively. The engaged employees are absorbed in their work that it is very difficult to distract them. Furthermore, self-managing career behavior may also have, directly or indirectly, an impact on organizational consequences such as training practices, performance, effectiveness, and turnover intentions.

4. Relationship between the Profile of the Respondents and their Career Opportunities

Table 2. Relationship between the Profile of the Respondents and their Career Opportunities

\begin{tabular}{|c|c|c|c|c|c|}
\hline \multirow[b]{2}{*}{ Profile } & & \multicolumn{4}{|c|}{ Career Opportunities } \\
\hline & & 焉营 & 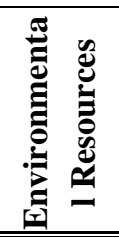 & 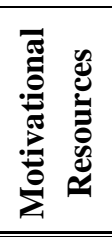 & 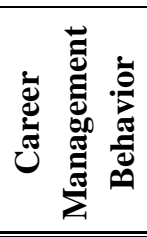 \\
\hline \multirow{2}{*}{ Age } & $\mathbf{r}$ & .076 & .000 & .178 & .118 \\
\hline & p-value & .416 & .996 & .055 & .206 \\
\hline \multirow{2}{*}{ Sex } & $\mathbf{r}$ & -.111 & -.021 & $-.207^{*}$ & $-.189^{*}$ \\
\hline & p-value & .234 & .824 & .025 & .041 \\
\hline \multirow{2}{*}{ Civil Status } & $\mathbf{r}$ & -.179 & $-.199^{*}$ & -.138 & -.120 \\
\hline & p-value & .054 & .031 & .138 & .198 \\
\hline \multirow{2}{*}{ Educational attainment } & $\mathbf{r}$ & $.259^{* *}$ & $.362^{* *}$ & .338 ** & $.283^{* *}$ \\
\hline & p-value & .005 & .000 & .000 & .002 \\
\hline \multirow{2}{*}{ Type of Work } & $\mathbf{r}$ & $.293^{* *}$ & $.219^{*}$ & $.255^{* *}$ & $.346^{* *}$ \\
\hline & p-value & .001 & .018 & .006 & .000 \\
\hline
\end{tabular}

ISSN: $2456-7620$ 


\begin{tabular}{cccccc} 
Status of Work & $\mathbf{r}$ & .022 & -.089 & .015 & .015 \\
& $\mathbf{p}$-value & .817 & .343 & .872 & .873 \\
Monthly Salary & $\mathbf{r}$ & .109 & -.084 & .101 & .044 \\
& $\mathbf{p}$-value & .242 & .368 & .279 & .639 \\
No. Of Promotion Last 5 & $\mathbf{r}$ & .161 & .156 & .141 & .142 \\
Years & $\mathbf{p}$-value & .084 & .093 & .130 & .126 \\
\hline \hline
\end{tabular}

It shows that the type of Educational attainment ( $\mathrm{r} .259 * *$ pvalue 005) and the Type of Work (r .293** p-value .001) are highly significant to Human Capital Resources. Moreover, educational attainment ( $\mathrm{r} .362 * * \mathrm{p}$-value .000$)$ is highly significant to Environmental Resources. Furthermore, Educational attainment ( $\mathrm{r} .338^{* *} \mathrm{p}$-value .000) and Type of Work ( $\mathrm{r} .255^{* *} \mathrm{p}$-value .006) are highly significant to Motivational Resources. Lastly, Educational attainment ( $\mathrm{r}$ $.283^{* *}$ p-value .002) and Type of Work ( $\mathrm{r} .346^{* *} \mathrm{p}$-value .000 ) are highly significant to Career Management Behavior, which is enough evidence to reject the hypothesis of the study. Thus, there is a significant relationship between the profile of the respondents and career opportunities. Thompson (2020) stated that there is a direct correlation between the level of education achieved and the likelihood of finding a job. The U.S. Bureau of Labor Statistics reported in 2013 that, at each higher level of education, the unemployment level drops. Higher education may be a requirement for promotions or for managerial positions. The article also stated that if you continue your education, you are eligible for this higher-paying, more prestigious jobs. If a job in the company opens up on a specific college major, the candidate will probably be the most competitive. Moreover, the Federal Reserve Bank of Cleveland (2011) published on their page that "labor market experiences can be highly varied for individuals with different levels of educational attainment. Higher levels of educational attainment tend to be associated with higher wages, and there is evidence that the benefits of a degree have been increasing in recent decades".

\section{Relationship between Educational Achievement and the Career Opportunities of the Respondents}

Table 3. Relationship between Educational Achievement and the Career Opportunities of the Respondents

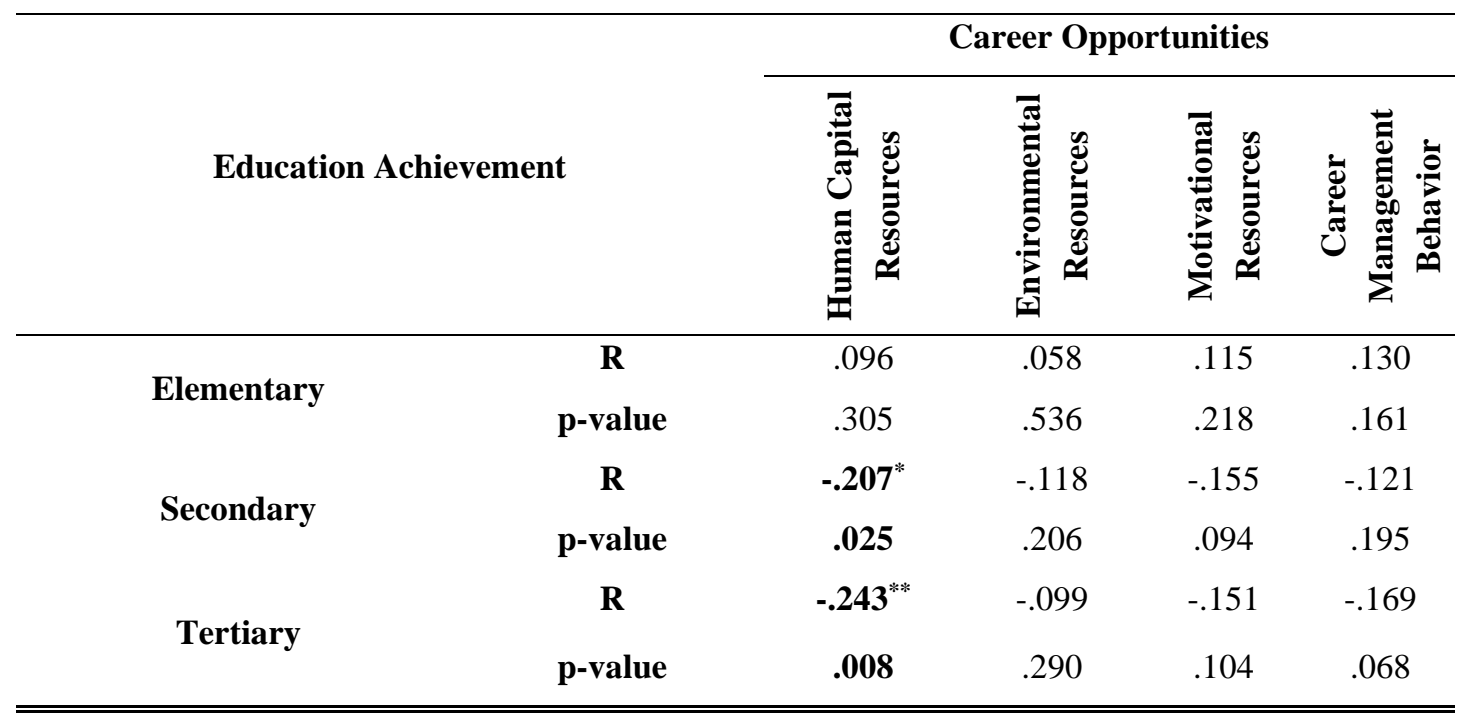


It shows that Secondary Level Achievement ( $\mathrm{r}-.207^{*} \mathrm{p}$ value .025) is significant to Human Capital Resources and Tertiary Level Achievement ( $\mathrm{r}-.243^{* *} \mathrm{p}$-value .008) is highly significant to Human Capital Resources, which is enough evidence to reject the hypothesis of the study. Thus, there is a significant relationship between the educational achievement of the respondents and career opportunities. Recent findings, that cognitive achievement is statistically important in determining workers' productivity imply that the academic performance of students in school has important implications for economic growth. "Student performance is also meant for making a difference locally, regionally, nationally andglobally (Farooq et.al., 2011)".Today's modern society expects everyone to be a high achiever. The key criteria to judge ones' true potentialities and capabilities are perhaps scholastic or academic achievement (Siwach, 2008). Academic achievement has become an index of a child's future. Mau and Bikos (2000) "declared that academic achievement was perhaps the single best predictor of occupational aspiration". "Lower achievement 20 may damper educational goals, which diverts students from certain academic activities and limit future occupationally related opportunities and experiences (Arbona, 2000)".Ritchie \& Bates (2013) state that greater knowledge helps children to be more informed citizens and better problem solvers. High achievement also open doors of opportunity in college education, which becomes an avenue for high-status employment that requires advanced training. Research shows that high achievers tend to have greater career success and higher income than lower achievers. The study also reveals that elementary achievement was not significantly correlated with career opportunities, the study of (Zhu \&Urhahne 2015) supported these findings and they stated that achievement rank tends to be fairly stable across childhood, whether measured by standardized test or GPA. That is, children who are high achievers at one age tend to be high achievers at another age, however, this does not mean that children never changed. Even though achievement is quite stable, it does not change for some students.

\section{CONCLUSIONS AND RECOMMENDATIONS}

The education achiever claimed that they have higher motivational resources in line with their career opportunities. Their profile variables such as educational attainment and type of work are highly correlated with career opportunities. Between the education achievement of the respondents and their career opportunities, Secondary level achievement was significantly correlated with career opportunities, and tertiary level achievement was highly significantly correlated with career opportunities. To support students with academic achievement, attain scholarship and career program that will guide them in their future career goals, the Department of Education (DepEd) and Commission on Higher Education (CHED) should collaborate. They should craft a strategic action plan (Mina, Subia \& Ermita, 2020) that would ensure better careers for these gifted individuals. Moreover, education achievers should pursue higher degrees for this will be very beneficial to their chosen career. For further study, continuous improvement of the (Alfonso, et.al.,2020) career guidance programs of the Department of Education may be proposed.

\section{REFERENCES}

[1] Arbona, C. (2000), The development of academic achievement of school-aged children. Precursors to career development. In S.D. Brown and R.W. Lent (Eds). Handbook of counseling, psychology, 3rd edition, pp 270-339, New York, Wiley.

[2] Alfonso, R., Leyesa, M., Lapiguera, D., Florencondia, N., Subia.G. (2020). Proposed Design for Framework Management of Cryptocurrency: Study of the Worldees First Digital Currency International Journal of Engineering Trends and Technology, 68(1),57-63.

[3] Aryee, S., Chay, Y. W. \& Tan, H. H. (1994). An examination of the antecedents of subjective career success among a managerial sample in Singapore, Human Relations, 47, 487509.

[4] Astin, A. W. (1999). Student Involvement: A Developmental Theory for Higher Education. Journal of College Student Development, 40(5), 518-29.

[5] Bakker, A. B., \& Leiter, M. P. (2010). Work Engagement; a handbook of theory and research. Taylor \& Francis e-Library, Hove and New-York.

[6] Boles, M., Pelletier, B. \& Lynch, W. (2004).The relationship between health risks and work productivity. Journal of Occupational and Environment Medicine, 46(7), 737-745.

[7] Farooq, M.S., Chaudhry, A.H., Shafiq, M., \&Berhanu, G. (2011). Factors affecting students' quality of academic performance: A case of secondary school level. Journal of Quality and Technology Management, 7(2), 01-14.

[8] Federal Reserve Bank of Cleveland (2011), Educational Attainment and Employment, retrieved from https://www.clevelandfed.org/en/newsroom-andevents/publications/economic-trends/2011-economictrends/et-20110302-educational-attainment-andemployment.aspx 
[9] Hirshi, et. Al (2018) Assessing Key Predictors of Career Success: Development and Validation of the Career Resources Questionnaire, Journal of Career Assessment, University of Bern,

[10] Ishak, S. (2015).Career Success Studies: An Examination of Indicators, Approach and Underlying Theories in Literature, School of Business Management, College of Business, Universiti Utara Malaysia, Sintok, Kedah DarulAman, Malaysia

[11] Judge, T.A., Cable, D.M., Boudreau, J.W. \&Bretz, R.D. (1995). An empirical investigation of the predictors of executive career success. Journal of Management, 48, 485519.

[12] Mau, W. and Bikos, L.H. (2000), Educational and Vocational Aspirations of minority and female students: a longitudinal study. Journal of Counseling and Development, 78, 186-194

[13] Mina, J., Subia, G. \&Ermita, P. (2020). Value Chain Analysis of Slipper Industry in the Footwear Capital of the North.Int. J Sup. Chain. Mgt Vol. 9, No. 5, 178-183.

[14] Murphy, S. E., \& Johnson, S. K. (2011). The benefits of a long-lens approach to leader development: Understanding the seeds of leadership. The Leadership Quarterly, 459-470

[15] Nassazi, Aidah (2013), Effects Of Training On Employee Performance. : Evidence from Uganda, retrieved from http://urn.fi/URN:NBN:fi:amk-2013120419934

[16] Ritchie, Stuart \& Bates, Timothy, (2013) Enduring Links From Childhood Mathematics and Reading Achievement to Adult Socioeconomic Status, Research Article Find in PubMed https://doi.org/10.1177/0956797612466268

[17] Robinson, A.; Shore,B. M.; Enersen, D.(2007) Best Practices in Gifted Education: An Evidence-Based Guide, Prufrock Press Inc. Retrieved at https://eric.ed.gov/?id=ED523594

[18] Shahibudin, I.(2015). Career Success Studies: An Examination of Indicators, Approach and Underlying Theories in Literature. Science Journal of Business and Management 3(6):251 DOI: 10.11648/j.sjbm.20150306.16

[19] Siwach, M. (2008), Impact of home environment on scholastic achievement of children. J. Hum. Ecol; 23(1), 7577.

[20] Steinmayr et. Al (2014). Academic Achievement. Achieved at

https://www.oxfordbibliographies.com/view/document/obo9780199756810/obo-9780199756810-0108.xml, Retrieved from November 21, 2019

[21] Story, P. A., Hart, J. W, Stasson, M. F. \& Mahoney J. M. (2009). Using a two-factor theory of achievement motivation to examine performance-based outcomes and self-regulatory processes. Personality and Individual differences, 46, 391-395

[22] Thompson, Van (2020), The Importance of Education in Finding a Job, Hearst Seattle Media, LLC retrieved from https://education.seattlepi.com/importance-education-findingjob-1207.html
[23] Zhu, Mingjing, Urhahne, Detlef (2015), Teachers' judgements of students' foreign-language achievement 10.1007/s10212014-0225-6, European Journal of Psychology of Education. 